\title{
Inter-observer variability with five computed tomography severity scales for COVID-19 pneumonia assessment
}

Karina I. Holguín-Andrade, * Estefanía Murrieta-Peralta, Ana P. Chischistz-Condey, Dania G. Solís-Cano, Roberto Ríos-Muñoz, Mario Calva-Arcos and Héctor Murrieta-González

Department of Radiology and Molecular Imaging, Centro Médico ABC, Mexico City, Mexico

\begin{abstract}
Introduction: By the end 2019 there was an outbreak of pneumonia caused by a new coronavirus, a disease that was called coronavirus disease 2019 (COVID-19). Computed tomography (CT) has played an important role in the diagnosis of COVID-19 patients. Objective: To demonstrate inter-observer variability with five scales proposed for measuring the extent of COVID-19 pneumonia on tomography. Methods: Thirty five initial chest CT scans of patients who attended respiratory triage for suspected COVID-19 pneumonia were analyzed. Three radiologists classified the tomographic images according to the severity scales proposed by Yang (1), Yuan (2), Chun (3), Wang (4) and Instituto Nacional de Enfermedades Respiratorias-Chung-Pan (5). The percentage of agreement between the evaluators for each scale was calculated using the intra-class correlation index. Results: In most patients were five pulmonary lobes compromised (77.1\% of the patients). Scales 1, 2, 4 and 5 showed an intra-class correlation $>0.91(p<0.0001)$, with agreement thus being almost perfect. Conclusions: Scale 4 (proposed by Wang) showed the best inter-observer agreement, with a coefficient of $0.964(p=0.001)$.
\end{abstract}

KEY WORDS: COVID-19 pneumonia. Inter-observer variability. Tomography severity scale.

\section{Variabilidad interobservador en cinco escalas de severidad determinada por tomografía computarizada para la valoración de neumonía por COVID-19}

\section{Resumen}

Introducción: A finales de 2019 se presentó un brote de neumonía causada por un nuevo coronavirus, enfermedad a la que se denominó COVID-19. La tomografía computarizada ha desempeñado un papel importante en el diagnóstico de los pacientes con COVID-19. Objetivo: Demostrar la variabilidad interobservador con cinco escalas propuestas para la medición de la extensión de la neumonía ocasionada por COVID-19 mediante tomografía. Métodos: Se analizaron 35 tomografías de tórax iniciales de pacientes que asistieron al triaje respiratorio por sospecha de neumonía por COVID-19. Tres radiólogos realizaron la clasificación de las imágenes tomográficas de acuerdo con las escalas de severidad propuestas por Yang (1), Yuan (2), Chun (3), Wang (4) e INER-Chung-Pan (5). Se calculó el porcentaje de concordancia entre los evaluadores para cada escala con el índice de correlación intraclase. Resultados: La mayoría de los pacientes presentó afección de cinco lóbulos pulmonares (77.1 \% de los pacientes). Las escalas 1, 2, 4 y 5 mostraron una correlación intraclase $>0.91$, con $p<0.0001$, por lo que la concordancia fue casi perfecta. Conclusiones: La escala 4 (de Wang) mostró la mejor concordancia interobservador, con un coeficiente de $0.964(p=0.001)$.

PALABRAS CLAVE: Neumonía por COVID-19. Variabilidad interobservador. Escala de severidad por tomografía. 


\section{Introduction}

By the end of 2019, an outbreak of pneumonia of unknown etiology occurred in Wuhan, Hubei province, China. In January 2020, these cases were determined to be secondary to a new virus, SARS-CoV-2. ${ }^{1}$ The disease caused by this new virus has been called coronavirus disease 2019 (COVID-19). ${ }^{2}$ This disease has had a rapid progression in the world and was therefore declared to be a pandemic in March 2020. ${ }^{3}$

For COVID-19 diagnosis, real-time polymerase chain reaction (RT-PCR) has been used as the reference standard, with sensitivity and specificity currently reported to be 42 to $71 \%$ at initial phases of the disease. ${ }^{4-6}$ This variability and low sensitivity of RTPCR imply that many patients with COVID-19 might not be identified at early stages. ${ }^{4}$

Computed tomography (CT) has played an important role in the diagnosis of patients with pneumonia associated with COVID-19. ' Several studies have described the characteristic tomographic patterns in patients with pneumonia secondary to COVID-19, 6,8,9 among which mainly ground glass opacity areas with or without association with areas of consolidation, of peripheral distribution and with predominance in lower lobes stand out. ${ }^{10}$ On the other hand, CT sensitivity in the presence of a positive RT-PCR test has been studied. These studies have shown a sensitivity of up to $97 \%$ for CT, with characteristic findings in the context of a positive RT-PCR test. ${ }^{11}$

Furthermore, the usefulness of CT imaging has been suggested as a mechanism to stratify lung disease severity. Multiple authors have proposed the use of tomographic severity indices for semi-quantitative measurement of pulmonary compromise, with involvement being evaluated by lung lobes, by lung segments or dividing both lungs into three areas. .2-15 $^{2}$

Among the tomography severity scales, five stand out:

1. Yang et al. scale, ${ }^{12}$ which assesses the percentage of involvement at each lung segment and stratifies it into three categories $(0,0 \%$ involvement; 1 , < 50\% involvement; $2,>50 \%$ involvement) and assigns a maximum score of 40

2. Yuan tomographic mortality scale, ${ }^{16}$ which divides each lung into three areas, and at each one evaluates pneumonia tomographic pattern ( 0 , normal; 1 , ground glass; 2, consolidation), which is multiplied by the percentage of involvement $(0$, normal; 1, <25\%; 2, 25-50\%; 3, 50-75\%; 4,> 75\%), with a maximum score of 72 being assigned
3. Wang's lung involvement scale. ${ }^{7}$ Although it is similar to the previous one, it eliminates the tomographic pattern variable, with maximum score therefore being 24 points

4. Chung's total severity scale, ${ }^{8}$ in which each lobe and its percentage of involvement is evaluated (0, 0\%; 1, 1-25\%; 2, 26-50\%; 3, 51-75\%; 4, 76-100\%) and a maximum score of 20 is assigned

5. A scale proposed by several authors such as Chung, Pan and their respective collaborators. ${ }^{17}$ This scale, recently incorporated to guidelines proposed by the National Institute of Respiratory Diseases (Instituto Nacional de Enfermedades Respiratorias [INER]) in Mexico, ${ }^{14}$ evaluates each lung lobe and multiplies it by the percentage of involvement, with an additional category being added: 1 , < 5\%; 2, 5-25\%; 3, 25-50\%; 4, $50-75 \% ; 5,>75 \%$. With this scale, a maximum score of 25 points is obtained.

Despite the usefulness of the described severity scales, inter-observer variability is not reported; in the scales proposed by Yang ${ }^{12}$ and Wang ${ }^{7}$ only intra-observer variability is indicated

The main purpose of this study is to demonstrate inter-observer variability of the aforementioned scales for measuring the extent of COVID-19 pneumonia by $\mathrm{CT}$.

\section{Methods}

Initial chest CT scans of patients who attended the respiratory triage for suspected COVID-19 pneumonia and who had a PCR positive test were analyzed.

To calculate the sample size, an expected agreement of $90 \%$ was used $(95 \%$ confidence interval $[\mathrm{Cl}]=80-100 \%)$, by means of which the estimated (and included) number of patients was 35 .

Chest CT was performed in the supine position following the protocol for chest examination: $2.5 \mathrm{~mm}$ slice thickness with reconstruction at $1.25 \mathrm{~mm}$ in the lung window, tube rotation time of $0.8 \mathrm{~s}, 1.375: 155.00$ pitch, 3.8-s exposure time with $120 \mathrm{kV}$ and $580 \mathrm{~mA}$.

Three radiologists with more than 5 years' experience in the CT department classified the CT images with the described five scales (Table 1), one scale per week. The images were randomly distributed each week among the three radiologists, a process that was continued until two evaluations of each scale per CT image were obtained.

The percentage of agreement between evaluators for each type of scale was calculated using the 
Table 1. Description of the scales for CT findings assessment in COVID-19 pneumonia

\begin{tabular}{|c|c|c|}
\hline Yang et al. ${ }^{12}$ & $\begin{array}{l}\text { It assesses each lung segment and assigns a score to the } \\
\text { degree of involvement: } 0,0 \% ; 1,<50 \% ; 2,>50 \%\end{array}$ & $\begin{array}{l}\text { Highest score is } 40 \text {. The threshold is }>19.5 \\
\text { points for severe disease and hospital admission }\end{array}$ \\
\hline Yuan et al. ${ }^{16}$ & $\begin{array}{l}\text { It divides both lungs into three areas, with the carina and } \\
\text { inferior pulmonary vein as limits for each. It assesses each } \\
\text { area and assigns a score to the degree of involvement: } \\
0,0 \% ; 1,<25 \% ; 2,25-50 \% ; 3,50-75 \% ; 4,>75 \% \text {. } \\
\text { Subsequently, it multiplies each assigned point by the } \\
\text { pattern that predominates at each area (1, normal; } \\
2 \text {, ground-glass opacity; } 3 \text {, consolidation) }\end{array}$ & $\begin{array}{l}\text { Highest score is } 72 \text {. The threshold for } \\
\text { predicting mortality is }>24.5 \text { points }\end{array}$ \\
\hline Chung et al. ${ }^{8}$ & $\begin{array}{l}\text { It assesses each lobe and assigns a score to the degree } \\
\text { of involvement: 0, normal; } 1-25 \% \text {, minimum; } 26-50 \% \text {, mild; } \\
51-75 \% \text {, moderate; }>75 \% \text {, severe }\end{array}$ & $\begin{array}{l}\text { Highest score is } 20 \text { points. It has no threshold } \\
\text { for correlating with clinical severity }\end{array}$ \\
\hline Wang et al. ${ }^{7}$ & $\begin{array}{l}\text { It divides both lungs into three areas, with the carina and } \\
\text { inferior pulmonary vein as limits for each. It assesses each } \\
\text { area and assigns a score to the degree of involvement: } \\
0,0 \% ; 1,<25 \% ; 2,25-50 \% ; 3,50-75 \% ; 4,>75 \%\end{array}$ & $\begin{array}{l}\text { Highest score is } 24 \text { points. It has no threshold } \\
\text { for correlating with clinical severity }\end{array}$ \\
\hline INER ${ }^{14} /$ Chung $^{9} /$ Pan et al. ${ }^{11}$ & $\begin{array}{l}\text { It assesses each lobe and assigns a score to the degree of } \\
\text { involvement: 0, normal; } 1,<5 \% ; 2,5-25 \% ; 3,26-50 \% \text {; } \\
4,51-75 \% ; 5,>75 \%\end{array}$ & $\begin{array}{l}\text { Highest score is } 25 \text { points. It divides the } \\
\text { disease into mild ( } 1-5 \text { points), moderate } \\
\text { ( } 5-15 \text { points) and severe ( }>15 \text { points) }\end{array}$ \\
\hline
\end{tabular}

Table 2. Demographic characteristics

\begin{tabular}{|c|c|c|}
\hline Age (years) & $\begin{array}{l}\text { Mean } \pm \text { standard deviation } \\
54.14 \pm 14.86\end{array}$ & $\begin{array}{l}\text { Range } \\
29-78\end{array}$ \\
\hline \multirow[t]{2}{*}{ Gender } & Females & $14(40 \%)$ \\
\hline & Males & $21(60 \%)$ \\
\hline \multirow[t]{4}{*}{ CT findings } & Ground-glass opacity & $21(60 \%)$ \\
\hline & Consolidation & $7(20 \%)$ \\
\hline & Crazy paving & $6(17.1 \%)$ \\
\hline & Negative & $1(2.9 \%)$ \\
\hline \multirow[t]{6}{*}{ Affected lobes } & 0 & $1(2.9 \%)$ \\
\hline & 1 & $0(0 \%)$ \\
\hline & 2 & $1(2.9 \%)$ \\
\hline & 3 & $3(8.6 \%)$ \\
\hline & 4 & $3(8.6 \%)$ \\
\hline & 5 & $27(77.1 \%)$ \\
\hline \multirow{2}{*}{$\begin{array}{l}\text { Pulmonary } \\
\text { emphysema }\end{array}$} & Negative & $29(82.9 \%)$ \\
\hline & Positive & $6(17.1 \%)$ \\
\hline \multirow[t]{2}{*}{ Pleural effusion } & Negative & $33(94.3 \%)$ \\
\hline & Positive & $2(5.7 \%)$ \\
\hline \multirow{2}{*}{$\begin{array}{l}\text { Outpatient } \\
\text { management }\end{array}$} & Negative & $32(91.4 \%)$ \\
\hline & Positive & $3(8.6 \%)$ \\
\hline \multirow{2}{*}{$\begin{array}{l}\text { Intensive care unit } \\
\text { admission }\end{array}$} & Negative & $16(45.7 \%)$ \\
\hline & Positive & $19(54.3 \%)$ \\
\hline \multirow[t]{2}{*}{ Intubation } & Negative & $19(54.3 \%)$ \\
\hline & Positive & $16(45.7 \%)$ \\
\hline
\end{tabular}

intra-class correlation index..$^{18,19}$ This is a measurement of the difference between observed agreement and expected agreement, although absolute scores were available for each scale. There is a classification for the degree of agreement, which it is considered by strata as follows: ${ }^{18}$

$-<0.3$, poor or no agreement

- 0.31-0.50, slight agreement

- 0.51-0.70, moderate agreement

- 0.71-0.90, good level of agreement

- > 0.91, almost perfect agreement.

In all cases, the threshold for assessing statistical significance was established at an alpha level of 0.05 .

Authorization was obtained from ABC Medical Center Ethics and Research Committee. There was no direct interaction with patients. The information was obtained from medical records, and patient confidentiality and anonymity was preserved.

\section{Results}

Thirty-five patients were studied, out of which $40 \%$ were females (14 patients) and 60\% males (21 patients), with a mean age of 54.14 years (Table 2).

Most patients had involvement of all five lobes ( $77.1 \%$ of the patients). The predominant tomographic pattern was ground-glass opacity in $21(60 \%)$, consolidation in seven $(20 \%)$ and "crazy paving" pattern in six $(17.1 \%)$.

The description of the method whereby pneumonia severity was evaluated according to each scale is shown in table 1. 
Table 3. Intra-class correlation results

\begin{tabular}{|c|c|c|c|c|c|}
\hline & \multicolumn{5}{|c|}{ Severity scale } \\
\hline & Yang et al. ${ }^{12}$ & Yuan et al. ${ }^{16}$ & Chung et al. ${ }^{8}$ & Wang et al. ${ }^{7}$ & INER ${ }^{14} /$ Chung et al. ${ }^{8} /$ Pan et al..$^{17}$ \\
\hline Intra-class correlation & 0.916 & 0.930 & -0.154 & 0.964 & 0.935 \\
\hline Intra-class correlation range & $0.834-0.958$ & $0.861-0.965$ & $-1.286-0.417$ & 0.928-0.982 & $0.872-0.967$ \\
\hline p-value & 0.001 & 0.001 & 0.661 & 0.001 & 0.001 \\
\hline
\end{tabular}

Table 4. Average score on each scale

\begin{tabular}{|c|c|c|c|}
\hline & Mean & Range & Standard deviation \\
\hline $\begin{array}{c}\text { Scale 1 } \\
\text { Reading 1 } \\
\text { Reading 2 }\end{array}$ & 20.71 & $0-40$ & 9.161 \\
\hline $\begin{array}{c}\text { Scale 2 } \\
\text { Reading 1 }\end{array}$ & 20.17 & $0-37$ & 8.793 \\
\hline Reading 2 & 27.83 & $0-66$ & 15.775 \\
\hline $\begin{array}{c}\text { Scale 3 } \\
\text { Reading 1 }\end{array}$ & 15.63 & $0-60$ & 14.250 \\
\hline $\begin{array}{c}\text { Reading 2 } \\
\text { Scale 4 } \\
\text { Reading 1 }\end{array}$ & 19.60 & $0-60$ & 13.226 \\
Reading 2 & 12.46 & $0-24$ & 12.360 \\
\hline $\begin{array}{c}\text { Scale 5 } \\
\text { Reading 1 } \\
\text { Reading 2 }\end{array}$ & 13.14 & $0-22$ & 5.972 \\
\hline
\end{tabular}

The scale that showed the best inter-observer agreement was the one proposed by Wang et al., ${ }^{7}$ with a coefficient of $0.964(95 \% \mathrm{Cl}, \mathrm{p}=0.001)$. The following in descending order of agreement was the scale proposed by Chung, Pan and their collaborators, ${ }^{17}$ which was adopted by INER ${ }^{14}$ and which in this study showed a coefficient of $0.935(95 \% \mathrm{Cl}, \mathrm{p}=0.001)$, followed by the scale by Yuan et al., ${ }^{16}$ with a coefficient of $0.930(95 \% \mathrm{Cl}, \mathrm{p}=$ 0.001 ). The scale that showed the lowest agreement was the one proposed by Chung et al., ${ }^{8}$ with a coefficient of $-0.154(95 \% \mathrm{Cl}, \mathrm{p}=0.661)$, as shown in table 3 .

Each scale has different scores, which range between 0 and 40, 72, 20, 24 and 25 points, respectively. Table 4 shows the average of the score assigned according to the two readings on each scale.

\section{Discussion}

The study population represents that which is reported in the literature. Most patients with COVID-19 pneumonia were males and had diffuse disease involving all five lung lobes. ${ }^{20}$

The patterns that were found were consistent with those reported in larger case series, ${ }^{21}$ both in frequency and order; the most common was ground-glass opacity, followed by the consolidation and crazy paving patterns. As mentioned by Zheng et al., ${ }^{6}$ one of the most common topographic manifestations is the presence of areas of involvement with ground-glass opacity images in up to $98 \%$ of patients, followed by consolidations in up to $64 \%$ of patients and crazy paving pattern in up to $36 \%$.

Some reports have also referred additional findings such as pleural effusion (8\%), ${ }^{22}$ which could confer higher risk for severe pneumonia requiring intubation, or even death. However, in this study, we only found two patients with pleural effusion (5.7\%): one had high scores on the different severity scales: 36 on that by Yang et al., ${ }^{12} 52$ on the scale by Yuan et al., ${ }^{16} 15$ on Chung et al. scale, ${ }^{8} 21$ on that by Wang et al. ${ }^{7}$ and 22 on the scale proposed by Chung-Pan-INER, which is correlated with the observation that patients with pleural effusion will have severe disease and, therefore, a different outcome. The second patient had scores close to the mean (21 on Yang et al. scale, ${ }^{12} 14$ on that by Yuan et al., ${ }^{16} 12$ on Chung et al. scale, ${ }^{8} 15$ on that by Wang et al. ${ }^{7}$ and 12 on the scale proposed by Chung-Pan-INER), which is why that observation would not apply to this patient.

This study is based on observations and measurements carried out in 35 patients, and the confidence intervals show the accuracy of the estimates.

The highest scores were observed in patients admitted to the intensive care unit and in intubated patients. Similarly, the lowest scores were recorded in patients managed on an outpatient basis. This indicates the usefulness of pulmonary severity classification as a prognostic indicator.

Regarding our main objective, we found that the majority of the scales have low inter-observer variability. However, scale 3 showed significant inter-observer variability, 
with an intra-class correlation of -0.154 , with a p-value < 0.661 , with correlation therefore being non-existent. The rest of the scales (1, 2, 4 and 5) had an intra-class correlation $>0.91$, with a $p$-value $<0.0001$, i.e., almost perfect. Thus, we found that, with the exception of number 3 , the scales can be used in clinical practice with greater confidence and less variability between observers.

We observed several aspects regarding a more specific analysis of each scale. One is that scales 1 and 2 are the most practical, since they are the only ones that propose a correlation of the score with a threshold for predicting hospital admission (scale 1) and mortality (scale 2). Scale 5 arbitrarily confers a degree of severity that does not translate into an outcome or specific clinical situation.

Scale 2 is particular, since it is the only one that assigns a score according to the extent of pneumonia, but also takes the pattern into account (ground-glass opacity or consolidation). Initially, we thought that the fact of introducing a second step, which is not carried out in the rest of the scales, would possibly increase inter-observer variability, which did not occur, although, at the moment, the observers considered that this scale had a higher degree of difficulty.

We thought that scales 3 and 5 would have less inter-observer variability, since they are the only ones that divide the evaluated areas according to anatomical limits that are observed on CT, given that they assess the extent of pneumonia by lobe, and the fissures that divide them are visible on the scan, and that the other scales, by conferring a non-visible anatomical limit (segments on scale 1 and three areas per lung on scales 2 and 4), would show higher inter-observer variability.

\section{Conclusions}

The majority of the evaluated scales had an almost perfect intra-class correlation and can therefore be used in daily practice. We do not recommend the use of the scale proposed by Chung et al., ${ }^{8}$ given that it had the highest inter-observer variability.

\section{Acknowledgments}

The authors thank Dr. Juan Osvaldo Talavera Piña collaboration.

\section{Conflict of interests}

The authors declare that they have no conflicts of interest.

\section{Funding}

The authors declare that they have not received any funding to carry out this study.

\section{Ethical disclosures}

Protection of human and animal subjects. The authors declare that no experiments were performed on humans or animals for this research.

Confidentiality of data. The authors declare that they followed the protocols of their work center on the publication of patient data.

Right to privacy and informed consent. The authors declare that no patient data appear in this article.

\section{References}

1. He F, Deng Y, Li W. Coronavirus disease 2019: what we know? J Med Virol. 2020;92:719-25.

2. World Health Organization. Clinical Management of Severe Acute Respiratory Infection (SARI) when COVID-19 Disease is Suspected. Switzerland: World Health Organization; 2020.

3. Simpson S, Kay FU, Abbara S, Bhalla S, Chung JH, Michael-Chung TS, et al. Radiological society of North America expert consensus statement on reporting chest CT findings related to COVID-19. Endorsed by the society of thoracic radiology, the american college of radiology, and RSNA. Radiol Cardiothorac Imaging. 2020;2:152.

4. Ai T, Yang Z, Hou H, Zhan C, Chen C, Lv W, et al. Correlation of chest CT and RT-PCR testing in coronavirus disease 2019 (COVID-19) in China: a report of 1014 cases. Radiology. 2020;296:E32-40.

5. Wen Z, Chi Y, Zhang L, Liu H, Du K, Li Z, et al. Coronavirus disease 2019: initial detection on chest CT in a retrospective multicenter study of 103 Chinese patients. Radiol Cardiothorac Imaging. 2020;2:e200092.

6. Zheng $Y$, Zhang $Y$, Wang $Y$, Zixiang H, Song B. Chest CT manifestations of new coronavirus disease 2019 (COVID-19): a pictorial review. Eur Radiol. 2020;30:4389-9.

7. Wang Y, Dong C, Hu Y, Li C, Ren W, Zhang X, et al. Temporal changes of CT findings in 90 patients with COVID-19 pneumonia: a longitudinal study. Radiology. 2020;296:E55-64.

8. Chung M, Bernheim A, Mei X, Zhang N, Huang M, Zeng X, et al. CT imaging features of 2019 novel coronavirus (2019-nCoV). Radiology. 2020;295:202-7.

9. Rubin GD, Ryerson CJ, Haramati LB, Sverzellati N, Kanne JP, Raoof S, et al. The role of chest imaging in patient management during the COVID-19 pandemic: a multinational consensus statement from the Fleischner society. Chest. 2020;158:106-16.

10. Pan Y, Guan H, Zhou S, Wang Y, Li Q, Zhu T, et al. Initial CT findings and temporal changes in patients with the novel coronavirus pneumonia (2019nnCoV): a study of 63 patients in Wuhan, China. Eur Radiol. 2020;30:3306-9.

11. Murrieta-Peralta E, Chischistz-Condey AP, Ramírez-Landero J, Moctezuma-Velasco CR, Murrieta-González H, Salazar-Segovia J. El reporte radiológico en pacientes con sospecha de COVID-19: nuestra experiencia en el Centro Médico ABC. An Radiol Mex. 2020;19:276-85.

12. Yang R, Li X, Liu H, Zhen Y, Zhang X, Xiong Q, et al. Chest CT severity score: an imaging tool for assessing severe COVID-19. Radiol Cardiothorac Imaging. 2020;30:e200047.

13. Kunwei L, Fang Y, Li W, Pan C, Qin P, Zhong Y, et al. CT image visual quantitative evaluation and clinical classification of coronavirus disease (COVID-19). Eur Radiol. 2020;30:4407-16.

14. Juárez-Hernández F. Presentación en Línea de la Página Oficial INER. Mexico: Instituto Nacional de Enfermedades Respiratorias; c2020.

15. Prokop $M$, van Everdingen $W$, van Rees-Vellinga $T$, van Ufford $H Q$, Stöger L, Beenen L, et al. CO-RADS a categorical CT assessment scheme for patients with suspected COVID-19: definition and evaluation. Radiology. 2020;296:E97-104.

16. Yuan M, Yin W, Tao Z, Tan W, Hu Y. Association of radiologic findings with mortality of patients infected with 2019 novel coronavirus in Wuhan, China. PLoS One. 2020;15:e0230548. 
17. Pan F, Ye T, Sun P, Gui S, Liang B, Li L, et al. Time course of lung changes at chest CT during recovery from coronavirus disease 2019 (COVID-19). Radiology. 2020;295:715-21.

18. Pita-Fernández S, Pértega-Díaz S, Rodríguez-Maseda E. La fiabilidad de las mediciones clínicas: el análisis de concordancia para variables numéricas. Cad Aten Primaria. 2003;10:290-6.

19. Camacho-Sandoval J. Coeficiente de concordancia para variables continuas. AMC. 2008;50:211-2.
20. Zhou S, Wang Y, Zhu T, Xia L. CT features of coronavirus disease 2019 (COVID-19) pneumonia in 62 patients in Wuhan, China. AJR Am J Roentgenol. 2020;214:1-8.

21. Salehi S, Abedi A, Balakrishnan S, Gholamrezanezhad A. Coronavirus disease 2019 (COVID-19): a systematic review of imaging findings in 919 patients. AJR Am J Roentgenol. 2020;215:1-7.

22. Carotti M, Salaffi F, Sarzi-Puttini P, Agostini A, Borgheresi A, Minorati D, et al. Chest CT features of coronavirus disease 2019 (COVID19) pneumonia: key points for radiologists. Radiol Med. 2020;2020:1-11. 